\title{
Assessment of Biomass and Carbon Stocks in Mangroves of Thalassery Estuarine Wetland of Kerala, South West Coast of India
}

\author{
Kavungal Vinod $^{\dagger *}$, Pillaru K. Asokan ${ }^{\dagger}$, Parayapanal Ulahannan Zacharia ${ }^{\dagger \dagger}$, Chalil Parambil Ansar ${ }^{\dagger}$, \\ Gokul Vijayan $^{+}$, Ashiyoda Anasukoya ${ }^{\dagger}$, Valiya Aliyammakkada Kunhi Koya ${ }^{\dagger}$, and \\ Moosamikkandi Nikhiljith ${ }^{\dagger}$ \\ ${ }^{\dagger}$ Calicut Research Centre of ICAR- \\ Central Marine Fisheries Research \\ Institute, Calicut, Kerala, India \\ $\pitchfork$ ICAR-Central Marine Fisheries \\ Research Institute, Kochi, Kerala, India \\ +Academy of Climate Change \\ Education and Research (ACCER) \\ Kerala Agricultural University \\ Thrissur, Kerala, India
}

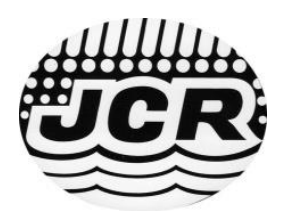

www.JCRonline.org

\begin{abstract}
Vinod, K.; Asokan, P.K.; Zacharia, P.U.; Ansar, C.P.; Vijayan, G.; Anasukoya, A.; Kunhi Koya, V.A., and Nikhiljith, M.K., 2019. Assessment of biomass and carbon stocks in mangroves of Thalassery estuarine wetland of Kerala, south-west coast of India. In: Jithendran, K.P.; Saraswathy, R.; Balasubramanian, C.P.; Kumaraguru Vasagam, K.P.; Jayasankar, V.; Raghavan, R.; Alavandi, S.V., and Vijayan, K.K. (eds.), BRAQCON 2019: World Brackishwater Aquaculture Conference. Journal of Coastal Research, Special Issue No. 86, pp. 209-217. Coconut Creek (Florida), ISSN 0749-0208.

The mangrove ecosystems render many goods and services ranging from coastal protection to climate regulation. These ecosystems are also reservoirs of carbon stocks, due to their ability to sequester and store carbon in their biomass and the underlying sediment, and therefore significant in view of the climate change mitigation. The present study attempted to assess the biomass and carbon stock of mangroves of Thalassery estuarine wetland of Kerala, south-west coast of India. We assessed the carbon stocks of three carbon pools viz., above-ground, below-ground (root) and sediment. A total of eight species of mangroves were recorded from the Thalassery estuarine wetland, and of these, Avicennia officinalis was the dominant species with an average tree density of 729.37 individuals ha $^{-1}$ and contributed most $\left(45.05 \pm 23.79 \mathrm{t} \mathrm{ha}^{-1}\right)$ to the total carbon. The overall mean above-ground biomass was $189.26 \pm 97.80$ $\mathrm{t} \mathrm{ha}^{-1}$, while the overall mean root biomass was $83.06 \pm 40.48 \mathrm{t} \mathrm{ha}^{-1}$. The estimated mean above-ground carbon was $94.63 \pm 48.90 \mathrm{t} \mathrm{C} \mathrm{ha}^{-1}$, while the mean carbon stock in root and sediment were $41.53 \pm 20.24 \mathrm{t} \mathrm{C} \mathrm{ha}^{-1}$ and $17.48 \pm 7.30 \mathrm{t}$ $\mathrm{C} \mathrm{ha}^{-1}$, respectively. In the present study, the estimates of mean combined C-stocks in mangrove and sediment showed that the mangroves of Thalassery estuarine wetland stored $153.64 \mathrm{t} \mathrm{C}^{-1} \mathrm{a}^{-1}$ which was equivalent to $563.86 \mathrm{t}$ $\mathrm{CO}_{2} \mathrm{ha}^{-1}$. The mangroves of Thalassery wetland cover an area of approximately 5.8 ha and thus it can be assumed that this wetland has the potential to sequester and store $891.11 \mathrm{t} \mathrm{C}$, equivalent to an estimated amount of $3270.37 \mathrm{t}$ $\mathrm{CO}_{2}$. The study reinforces the importance of mangrove forests as useful carbon sinks and the need for protection of these critical habitats in the light of climate change mitigation.
\end{abstract}

\section{ADDITIONAL INDEX WORDS: Carbon sequestration, carbon stocks, mangroves, Thalassery.}

\section{INTRODUCTION}

The concentration of atmospheric carbon-di-oxide has been on the rise since the beginning of the industrial revolution (Dedysh, Derakshani, and Liesack, 2001; Le Quere et al., 2012) resulting in consequences like the warming of the planet, change in precipitation patterns and rising sea level. The forests are reservoirs of sequestered carbon stocks and the global community has already started realizing the importance of forest ecosystems in the light of climate change. The forests act as a sink of carbon-di-oxide when conserved, but as a source when destroyed.

The coastal ecosystems of mangroves, tidal marshes and seagrass meadows are reservoirs of carbon stored over centuries. These ecosystems have the potential to sequester and store large quantities of carbon (often referred to as 'blue carbon') per unit area when compared to the terrestrial forests.

DOI: 10.2112/SI86-031.1 received 18 May 2019; accepted in revision 28 May 2019.

*Corresponding author: vinod_kavungal@yahoo.co.in

${ }^{\oplus}$ Coastal Education and Research Foundation, Inc. 2019
As a result, the blue carbon ecosystem is recognized for its significant role in mitigating climate change. The mangrove forests have a special place owing to their ability to sequester substantial quantity of atmospheric $\mathrm{CO}_{2}$ and store carbon in their biomass and sediments (Chen et al., 2012; Kauffman and Donato, 2012; Murdiyarso et al., 2009). Although mangroves contribute only a mere $0.7 \%$ of tropical forests of the world (Giri et al., 2011), these forests have the potential to store up to 20 billion tons of carbon, which is much higher than the carbon stock in tropical upland, temperate and boreal forests (Donato et $a l ., 2011)$. Thus, it is interesting to note that the mangrove forests sequester four times more carbon per unit area than the terrestrial forests of the tropics (Donato et al., 2011; Khan, Suwa, and Hagihara, 2007).

The mangrove forests render several ecosystem services and functions in addition to carbon sequestration. They are important in maintaining the coastal water quality, act as a nutrient filter between land and sea, helps in coastline protection, as breeding and nursery ground for many important fishes and invertebrates and support coastal fisheries (Alongi, Tirendi, and Clough, 2000; Baran and Hambrey, 1998; Barbier, 2000 ; Diele, Koch, 


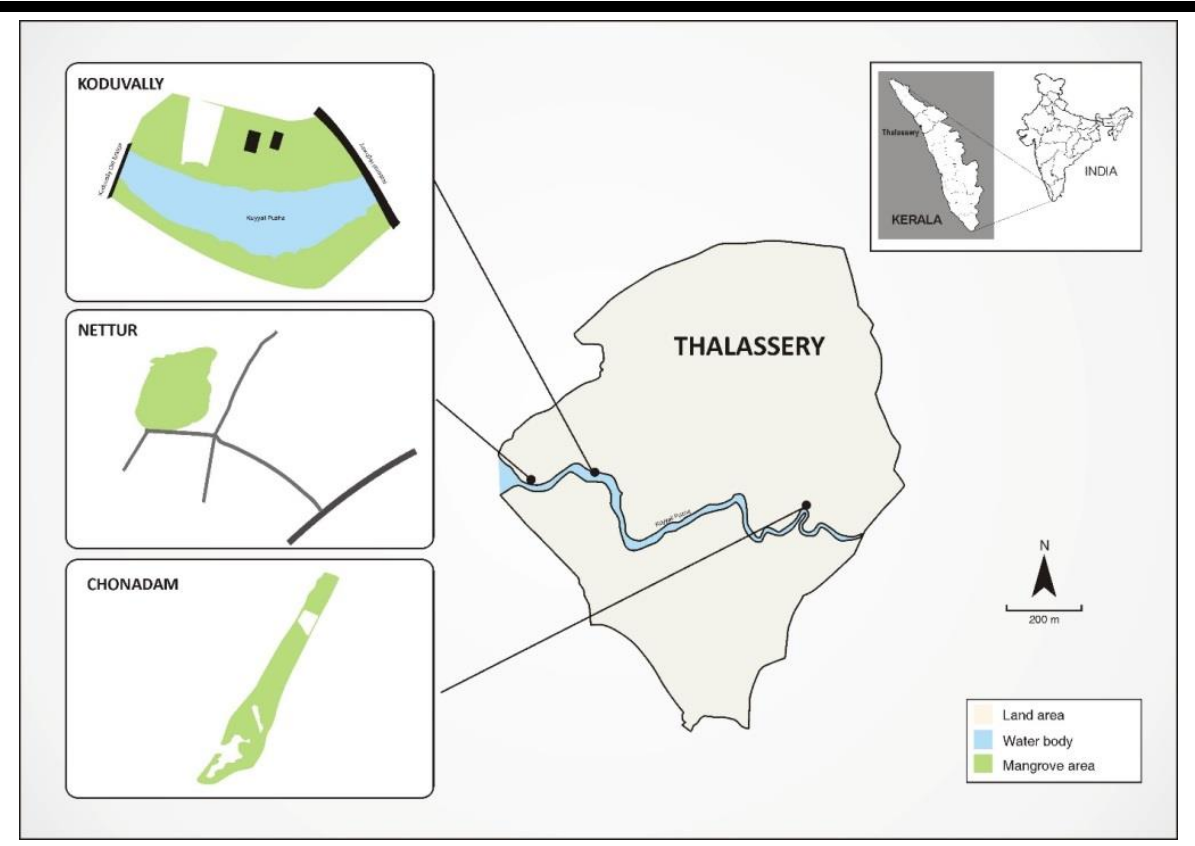

Figure 1. Map of Thalassery showing the study area.

and Saint-Paul, 2005; Field, 1995; Monroy et al., 1999; Mumby et al., 2004; Rivera-Robertson and Phillips, 1995; Ronnback, 1999; Vermaat and Thampanya, 2006; Yoshiro et al., 1997). Although being an ecologically and economically important ecosystem, the mangroves are one of the most threatened ecosystems, mainly due to anthropogenic pressures. The degradation of mangroves is caused mainly due to the conversion of mangrove areas for agriculture, aquaculture, urban development and tourism (Sahu et al., 2013; Upadhyay, Ranjan, and Singh, 2002).

Reduction in mangrove area will increase the threat to human safety as the coastal ecosystems become more vulnerable to storm waves, cyclones and erosion (Danielsen et al., 2005; Danielsen et al., 2006; Das and Vincent, 2009; Kathiresan and Rajendran, 2005; Roy and Krishnan, 2005). The reduction in mangrove area also leads to loss of potential carbon sinks and their destruction might lead to greater emissions of carbon-dioxide back into the air and ocean.

Globally, mangroves are distributed in over 123 countries and territories in the tropical and sub-tropical region, with a total mangrove cover of 150,000 sq. km. (Spalding, Kainuma, and Collins, 2010). In India, mangroves are spread over an area of 4921 sq. km, which is about $3.3 \%$ of the mangrove vegetation distributed globally (India State of Forest Report, 2017).

Considering the vastness of mangrove cover in India, substantial amounts of atmospheric carbon-di-oxide is expected to be sequestered and stored by this halophytic vegetation. Kerala, the southern state of India has a total mangrove cover of 9 sq. km. (India State of Forest Report, 2017) with the highest area of $6 \mathrm{sq}$. km. spread in the Kannur district of the state. The present study is a focused attempt to understand the biomass and carbon stocks of mangroves of Thalassery estuary, an important mangrove wetland of Kannur district of Kerala, south-west coast of India.

\section{METHODOLOGY}

Thalassery is an important estuarine region in the Kannur district of Kerala, south-west coast of India. The mangroves of Thalassery estuary is found distributed in three large patches viz., Nettur, Koduvally and Chonadam (Figure 1). Nettur (sector I) has an area of 1.8 ha while Koduvally (sector II) and Chonadam (sector III) has 2 ha each.

\section{Field Sampling}

The study was conducted from April 2017 to March 2018. A total of 17 sampling plots (6 in the sector I, 7 in sector II and 4 in sector III) each of $10 \mathrm{~m} \times 10 \mathrm{~m}$ size were established through a non-destructive stratified random quadrat sampling technique to determine the composition of mangroves, tree density and carbon stock. The total sampling area covered was 0.17 ha.

A Global Positioning System, GPS (Garmin GPS map $76 \mathrm{CSx}$ ) was used to mark the exact location of each sampling station and the geospatial locations of each sampling station are given in Table 1.

\section{Tree Measurements}

The girth of every individual mangrove tree of the study quadrat was measured. The tree girth measurements were taken at breast height which is $1.3 \mathrm{~m}$ above the ground. The tree girth measurements were then converted to diameter at breast height (DBH) measurement by dividing by $\pi$ (Frontier Madagascar, 2005). All adult trees and saplings of height $1.3 \mathrm{~m}$ and above 


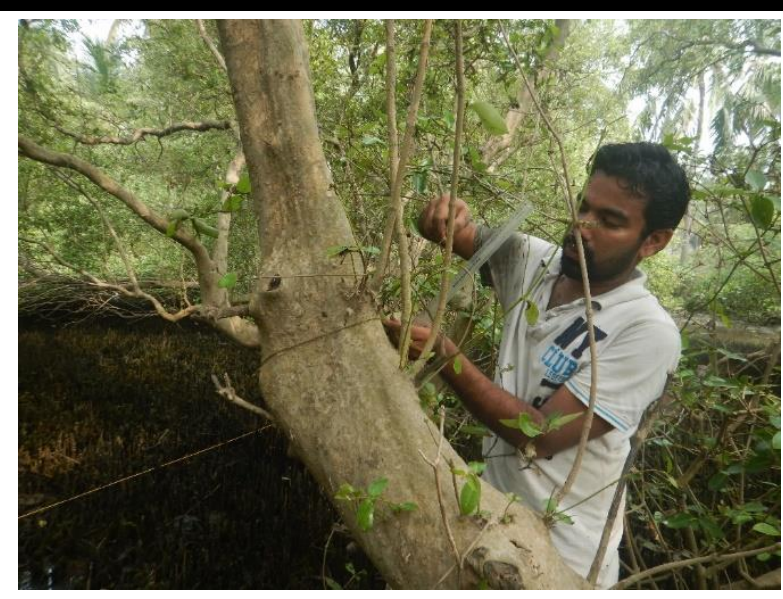

(a)

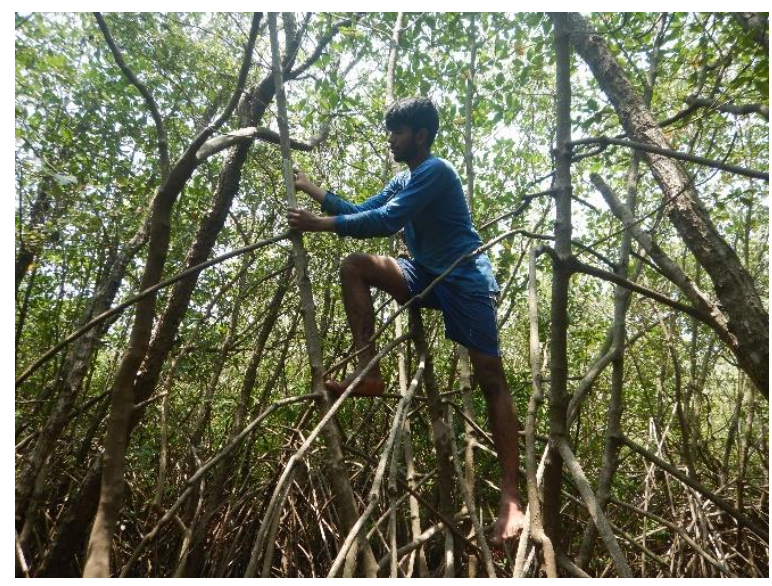

(b)

Figure 2. Measurement of DBH of (a) Avicennia marina and (b) Rhizophora mucronata.

were considered for the measurement of DBH (Figure 2). In Rhizophora mucronata, the trunk diameter at $30 \mathrm{~cm}$ above the highest prop root was measured (Komiyama, Poungparn, and Kato, 2005).

Table 1. Study stations in Thalassery mangrove wetland and their geospatial locations.

\begin{tabular}{lcc}
\hline \hline Sectors & $\begin{array}{c}\text { Stations / } \\
\text { Quadrats }\end{array}$ & GPS locations \\
\hline Sector I & 1 & $11^{\circ} 46.309^{\prime \prime} \mathrm{N} ; 075^{\circ} 28.408^{\prime \prime} \mathrm{E}$ \\
Nettur & 2 & $11^{\circ} 46.318^{\prime \prime} \mathrm{N} ; 075^{\circ} 28.418^{\prime \prime} \mathrm{E}$ \\
& 3 & $11^{\circ} 46.327^{\prime \prime} \mathrm{N} ; 075^{\circ} 28.430^{\prime \prime} \mathrm{E}$ \\
& 4 & $1^{\circ} 46.352^{\prime \prime} \mathrm{N} ; 075^{\circ} 28.455^{\prime \prime} \mathrm{E}$ \\
& 5 & $11^{\circ} 46.372^{\prime \prime} \mathrm{N} ; 075^{\circ} 28.425^{\prime \prime} \mathrm{E}$ \\
Sector II & 6 & $11^{\circ} 46.320^{\prime \prime} \mathrm{N} ; 075^{\circ} 28.438^{\prime \prime} \mathrm{E}$ \\
Koduvally & 1 & $11^{\circ} 45.956^{\prime \prime} \mathrm{N} ; 075^{\circ} 28.696^{\prime \prime} \mathrm{E}$ \\
& 2 & $11^{\circ} 46.320^{\prime \prime} \mathrm{N} ; 075^{\circ} 28.438^{\prime \prime} \mathrm{E}$ \\
& 3 & $11^{\circ} 45.927 " \mathrm{~N} ; 075^{\circ} 28.672^{\prime \prime} \mathrm{E}$ \\
& 4 & $1^{\circ} 45.520^{\prime \prime} \mathrm{N} ; 075^{\circ} 28.470^{\prime \prime} \mathrm{E}$ \\
Sector III & 5 & $11^{\circ} 46.101^{\prime \prime} \mathrm{N} ; 075^{\circ} 28.301^{\prime \prime} \mathrm{E}$ \\
Chonadam & 6 & $11^{\circ} 46.100^{\prime \prime} \mathrm{N} ; 075^{\circ} 28.210^{\prime \prime} \mathrm{E}$ \\
& 7 & $1^{\circ} 46.108^{\prime \prime} \mathrm{N} ; 075^{\circ} 28.217^{\prime \prime} \mathrm{E}$ \\
& 2 & $11^{\circ} 45.776^{\prime \prime} \mathrm{N} ; 075^{\circ} 30.968^{\prime \prime} \mathrm{E}$ \\
& 3 & $11^{\circ} 45.748^{\prime \prime} \mathrm{N} ; 075^{\circ} 30.954^{\prime \prime} \mathrm{E}$ \\
& 4 & $11^{\circ} 45.723^{\prime \prime} \mathrm{N} ; 075^{\circ} 30.937^{\prime \prime} \mathrm{E}$ \\
& & $11^{\circ} 45.509^{\prime \prime} \mathrm{N} ; 075^{\circ} 30.470^{\prime \prime} \mathrm{E}$ \\
\hline
\end{tabular}

The mangrove plants/trees were classified as seedlings, saplings and adults based on their total height and girth at breast height. The plants which were less than $1 \mathrm{~m}$ tall were classified as seedlings. The plants taller than $1 \mathrm{~m}$, but less than $4 \mathrm{~cm}$ girth at breast height were classified as saplings, while the plants taller than $1 \mathrm{~m}$ with greater than $4 \mathrm{~cm}$ girth at breast height were considered as adults (Frontier Madagascar, 2005).

All adult trees present in each of the quadrats were measured for the estimation of above-ground biomass, below-ground biomass and carbon stock. However, the understory vegetation of seedlings and herbs is considered to be negligible and hence not considered for measurement of ecosystem carbon pools (Kauffman and Donato, 2012).

Also, litter being a small component of the total ecosystem, carbon stock is not usually sampled (Kauffman and Donato, 2012). All the dead trees were also taken into consideration and the biomass of dead trees was estimated based on the 'decay status categories' following the methods outlined by Kauffman and Donato (2012).

\section{Biomass and Carbon Stock Estimation}

For the estimation of carbon, three pools of carbon viz., above-ground biomass, below-ground biomass (root) and sediment were considered. The allometric equations developed by Komiyama, Poungparn, and Kato (2005) for south-east Asia were used for the estimation of above-ground biomass ( $\mathrm{W}_{\text {top }}$ ) and below-ground biomass $\left(\mathrm{W}_{\mathrm{R}}\right)$. The allometric equations are:

$$
\begin{aligned}
& \mathrm{W}_{\text {top }}=0.251 \rho \mathrm{D}^{2.46} \\
& \mathrm{~W}_{\mathrm{R}}=0.199 \rho^{0.899} \mathrm{D}^{2.22}
\end{aligned}
$$

Where, $\rho$ is the wood density of the respective species and D is the Diameter at Breast Height (DBH). The wood densities of different mangrove species were obtained from the World Agroforestry Database (World Agroforestry Centre, 2011).

The total biomass of mangrove trees was obtained by summing up the values obtained for the above-ground and below-ground biomass for all the plots. These values were then averaged to get the mean total biomass, which was finally converted to tonnes per hectare. The biomass values were converted to carbon through the use of a carbon fraction value of $50 \%$.

\section{Soil Sampling and Analysis}

A PVC core sampler having a length of $1 \mathrm{~m}$ and $4 \mathrm{~cm}$ diameter was used to collect sediment samples from each quadrat (Figure 3) in the study area. The sediment sample from 
surface to $30 \mathrm{~cm}$ depth was collected during each core sampling and the collected samples were stored in clean polythene bags for the estimation of organic carbon. Sediment samples were also collected using the core from each plot for the estimation of sediment bulk density. The sediment samples for estimation of bulk density were oven-dried and the bulk density was calculated by dividing the dry weight of the core sample by the volume of the core. The organic carbon in sediment samples was estimated following the method of Walkley and Black (1934). The sediment organic carbon was determined using the formula:

Sediment organic carbon $(\mathrm{t} / \mathrm{ha})=$ Bulk density $\left(\mathrm{g} \mathrm{cm}^{-3}\right) \mathrm{x}$ sediment depth $(\mathrm{cm}) \mathrm{x}$ organic Carbon $(\%)$

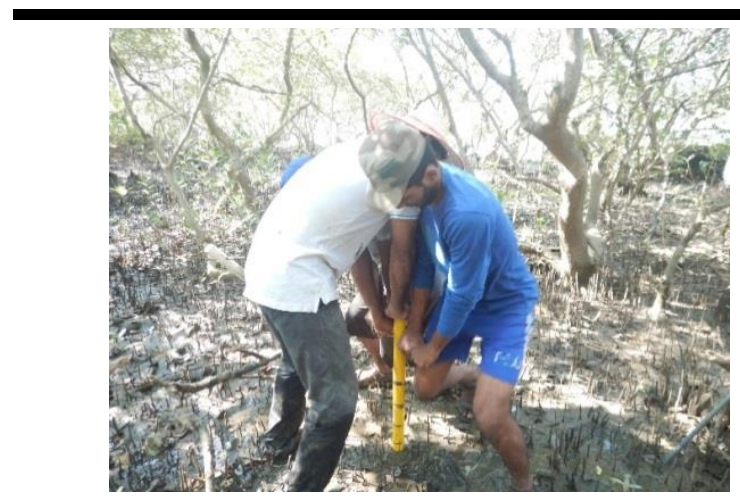

Figure 3. Sediment sampling using a PVC core.

\section{RESULTS}

The floristic composition and tree density of mangroves in three different sectors of Thalassery estuarine wetland were studied and documented. The carbon stock in three different carbon pools namely above-ground, below-ground (root) and sediment were estimated to arrive at the total carbon stock of Thalassery wetland.

Table 2. Floristic composition of mangroves in different sectors of the study area.

\begin{tabular}{lccc}
\hline Species & \multicolumn{3}{c}{ Sectors } \\
\hline & Sector I & Sectors II & Sectors III \\
Nettur & Koduvally & Chonadam \\
Avicennia officinalis & $\sqrt{ }$ & $\sqrt{ }$ & $\sqrt{ }$ \\
Avicennia marina & $\sqrt{ }$ & $\sqrt{ }$ & $\times$ \\
Sonneratia alba & $\sqrt{ }$ & $\sqrt{ }$ & $\times$ \\
Bruguiera sexangula & $\sqrt{ }$ & $\sqrt{ }$ & $\times$ \\
Aegiceras corniculatum & $\sqrt{ }$ & $\sqrt{ }$ & $\times$ \\
Excoecaria agallocha & $\times$ & $\sqrt{ }$ & $\times$ \\
Kandelia candel & $\times$ & $\times$ & $\sqrt{ }$ \\
\hline
\end{tabular}

\section{Floristic Composition}

A total of eight species of mangroves viz., Rhizophora mucronata (Family: Rhizophoraceae), Avicennia officinalis (Family: Avicenniaceae), Avicennia marina (Family: Avicenniaceae), Sonneratia alba (Family: Lythraceae), Bruguiera sexangula (Family: Rhizophoraceae), Aegiceras corniculatum (Family: Myrsinaceae), Excoecaria agallocha (Family: Euphorbiaceae) and Kandelia candel (Family:
Rhizophoraceae) which belonged to 7 genera and 5 families were found distributed in different sectors of the Thalassery mangrove wetland. A total of six species were found in the sector I, while 7 species were recorded from sector II and only 3 species from sector III (Table 2). Two species namely $E$. agallocha and $K$. candel were found to have sparse distribution; while the former was found only in sector II, the latter was recorded only in sector III.

\section{Mangrove Tree Density and Diameter at Breast Height (DBH)}

A total of 405 individual stems (391 live and 14 dead) were recorded and studied from 0.17 ha of the sampling area. Among the eight species, A. officinalis was the dominant species with an average tree density of $729.37 \pm 693.48$ individuals ha ${ }^{-1}$, followed by $S$. alba with an average tree density of $477.78 \pm 587.21$ and $A$. marina with a tree density of $471.43 \pm 418.70$ individuals ha $^{-1}$ (Table 3). The average tree densities of $R$. mucronata and $K$. candel were $419.44 \pm 360.97$ and $275.0 \pm 476.31$ individuals ha $^{-1}$ respectively, while that of $B$. sexangula was $63.49 \pm 66.89$ individuals $\mathrm{ha}^{-1}$. The tree density was low in the case of $E$. agallocha $\left(9.52 \pm 16.49\right.$ individuals $\left.\mathrm{ha}^{-1}\right)$ while the density was lowest in A. corniculatum (5.56 \pm 9.62 individuals ha ${ }^{-1}$ ).

The diameter at breast height of different mangrove species of the study area ranged from $3.04 \pm 1.45 \mathrm{~cm}$ (A. corniculatum) to $11.80 \pm 4.02 \mathrm{~cm}(S$. alba). The DBH of A. officinalis was also high $(9.86 \pm 4.03 \mathrm{~cm})$, but was only next to $S$. alba. The DBH values of A. marina and E. agallocha were $8.35 \pm 4.96 \mathrm{~cm}$ and $5.73 \pm 3.57 \mathrm{~cm}$ respectively (Table 3 ), while the $\mathrm{DBH}$ values were $4.52 \pm 4.52,4.29 \pm 1.18,3.31 \pm 2.05$ and $3.04 \pm 1.45 \mathrm{~cm}$ for $A$. corniculatum, $K$. candel, $R$. mucronata and B. sexangula, respectively.

\section{Biomass and C-stock}

The mean above-ground biomass, below-ground biomass (root) and the total biomass of different mangrove species recorded in the study area are given in Table 4 . The highest biomass of $90.10 \pm 47.57 \mathrm{t} \mathrm{ha}^{-1}$ (AGB of $63.53 \pm 34.26 \mathrm{t} \mathrm{ha}^{-1}$ and root biomass of $26.57 \pm 13.31 \mathrm{t} \mathrm{ha}^{-1}$ ) was recorded in $A$. officinalis (Table 4) which was the dominant species in the study region with the highest tree density. The lowest biomass of $0.06 \pm 0.57 \mathrm{t} \mathrm{ha}^{-1}$ (AGB of $0.04 \pm 0.36 \mathrm{tha}^{-1}$ and root biomass of $0.02 \pm 0.21 \mathrm{t} \mathrm{ha}^{-1}$ ) was recorded in A. corniculatum.

Among the mangrove species of Thalassery wetland, $A$. officinalis was the species that contributed most to the total carbon $\left(45.05 \pm 23.79 \mathrm{t} \mathrm{ha}^{-1}\right)$, followed by $S$. alba $(44.48 \pm 30.71 \mathrm{t}$ $\left.\mathrm{ha}^{-1}\right), \quad R$. mucronata $\left(22.82 \pm 2.36 \mathrm{t} \mathrm{ha}^{-1}\right)$ and $A$. marina $\left(22.37 \pm 19.77 \mathrm{t} \mathrm{ha}^{-1}\right)$. The total carbon values of $B$. sexangula $\left(0.41 \pm 0.97 \mathrm{t} \mathrm{ha}^{-1}\right), K$. candel $\left(0.90 \pm 0.36 \mathrm{t} \mathrm{ha}^{-1}\right)$, E. agallocha $\left(0.11 \pm 0.56 \mathrm{t} \mathrm{ha}^{-1}\right)$ and A. corniculatum $\left(0.03 \pm 0.29 \mathrm{t} \mathrm{ha}^{-1}\right)$ were less in Thalassery wetland due to their sparse distribution (Table 4).The biomass and carbon stocks of mangroves in different stations of Thalassery estuarine wetland is presented in Table 5. The overall mean above ground biomass (AGB) was 189.26 $\pm 97.80 \mathrm{t} \mathrm{ha}^{-1}$, while the overall mean root biomass was $83.06 \pm 40.48 \mathrm{t} \mathrm{ha}^{-1}$. The mean AGB values in different sectors ranged from $171.95 \pm 129.50 \mathrm{t} \mathrm{ha}^{-1}$ (sector I) to $238.47 \pm 87.87 \mathrm{t}$ $\mathrm{ha}^{-1}$ (sector III), while the mean root biomass ranged from 
Table 3. Average Diameter at Breast Height (DBH) and tree density of different mangrove species in the Thalassery estuarine wetland.

\begin{tabular}{clcc}
\hline \hline Sl. No. & Species & Average DBH $(\mathrm{cm})$ & $\begin{array}{c}\text { Tree density } \\
\text { (individuals ha }\end{array}$ \\
\hline 1 & Rhizophora mucronata & $3.31 \pm 2.05$ & $419.44 \pm 360.97$ \\
2 & Avicennia officinalis & $9.86 \pm 4.03$ & $729.37 \pm 693.48$ \\
3 & Avicennia marina & $8.35 \pm 4.96$ & $471.73 \pm 418.70$ \\
4 & Sonneratia alba & $11.80 \pm 4.02$ & $477.78 \pm 587.21$ \\
5 & Bruguiera sexangula & $3.04 \pm 1.45$ & $63.49 \pm 66.89$ \\
6 & Aegiceras corniculatum & $4.52 \pm 4.52$ & $5.56 \pm 9.62$ \\
7 & Excoecaria agallocha & $5.73 \pm 3.57$ & $9.52 \pm 16.49$ \\
8 & Kandelia candel & $4.29 \pm 1.18$ & $275.0 \pm 476.31$ \\
\hline
\end{tabular}

Table 4. Biomass and carbon stock of different mangrove species of Thalassery wetland (overall mean of stations with standard deviation).

\begin{tabular}{|c|c|c|c|c|c|c|}
\hline Species & $\begin{array}{l}\text { Above-ground biomass } \\
(\mathrm{AGB})\left(\mathrm{t} \mathrm{ha}^{-1}\right)\end{array}$ & $\begin{array}{l}\text { Above Ground } \\
\text { Carbon }(\mathrm{t} \mathrm{C} \mathrm{ha-1)}\end{array}$ & $\begin{array}{l}\text { Root biomass } \\
\left(\mathrm{t} \mathrm{ha}^{-1}\right)\end{array}$ & $\begin{array}{l}\text { Root Biomass } \\
\text { Carbon (t C ha-1) }\end{array}$ & $\begin{array}{l}\text { Total biomass } \\
\left(\mathrm{t} \mathrm{ha}^{-1}\right)\end{array}$ & $\begin{array}{l}\text { Total Carbon } \\
\left(\mathrm{t} \mathrm{C} \mathrm{ha}^{-1}\right)\end{array}$ \\
\hline Rhizophora mисronata & $29.90 \pm 3.15$ & $14.95 \pm 1.58$ & $15.74 \pm 1.56$ & $7.87 \pm 0.78$ & $45.64 \pm 4.71$ & $22.82 \pm 2.36$ \\
\hline Avicennia officinalis & $63.53 \pm 34.26$ & $31.77 \pm 17.13$ & $26.57 \pm 13.31$ & $13.29 \pm 6.66$ & $90.10 \pm 47.57$ & $45.05 \pm 23.79$ \\
\hline Avicennia marina & $31.07 \pm 28.27$ & $15.54 \pm 14.14$ & $13.66 \pm 11.25$ & $6.83 \pm 5.63$ & $44.74 \pm 39.52$ & $22.37 \pm 19.77$ \\
\hline Sonneratia alba & $62.93 \pm 44.25$ & $31.47 \pm 22.13$ & $26.03 \pm 17.16$ & $13.02 \pm 8.58$ & $88.96 \pm 61.41$ & $44.48 \pm 30.71$ \\
\hline Bruguiera sexangula & $0.53 \pm 1.27$ & $0.27 \pm 0.64$ & $0.29 \pm 0.66$ & $0.15 \pm 0.33$ & $0.82 \pm 1.93$ & $0.41 \pm 0.97$ \\
\hline Aegiceras corniculatum & $0.04 \pm 0.36$ & $0.02 \pm 0.18$ & $0.02 \pm 0.21$ & $0.01 \pm 0.11$ & $0.06 \pm 0.57$ & $0.03 \pm 0.29$ \\
\hline Excoecaria agallocha & $0.13 \pm 0.73$ & $0.07 \pm 0.37$ & $0.07 \pm 0.37$ & $0.04 \pm 0.19$ & $0.19 \pm 1.10$ & $0.11 \pm 0.56$ \\
\hline Kandelia candel & $1.14 \pm 0.47$ & $0.57 \pm 0.24$ & $0.65 \pm 0.24$ & $0.33 \pm 0.12$ & $1.79 \pm 0.71$ & $0.90 \pm 0.36$ \\
\hline
\end{tabular}

$74.64 \pm 53.66 \mathrm{t} \mathrm{ha}^{-1}$ (sector I) to $98.70 \pm 32.30 \mathrm{t} \mathrm{ha}^{-1}$ (sector III). The above-ground Carbon ranged from $85.98 \pm 64.75 \mathrm{t} \mathrm{ha}^{-1}$ (sector I) to $119.24 \pm 43.94 \mathrm{t} \mathrm{C} \mathrm{ha}^{-1}$ (sector III) with an overall mean value of $94.63 \pm 48.90 \mathrm{t} \mathrm{C} \mathrm{ha}^{-1}$, while the carbon stock in root ranged from $37.32 \pm 26.83$ (sector I) to $49.35 \pm 16.15 \mathrm{t} \mathrm{C} \mathrm{ha}^{-1}$ (sector III), with a mean carbon value of $41.53 \pm 20.24 \mathrm{t} \mathrm{C} \mathrm{ha}^{-1}$. The total mean biomass of Thalassery mangrove was found to be $272.32 \pm 138.27 \mathrm{t} \mathrm{ha}^{-1}$. Of the three sectors, the highest mean biomass was recorded in sector III $\left(337.17 \pm 120.17 \mathrm{t} \mathrm{ha}^{-1}\right)$, while the lowest mean biomass was recorded in the sector I $\left(246.59 \pm 183.16 \mathrm{t} \mathrm{ha}^{-1}\right)$.

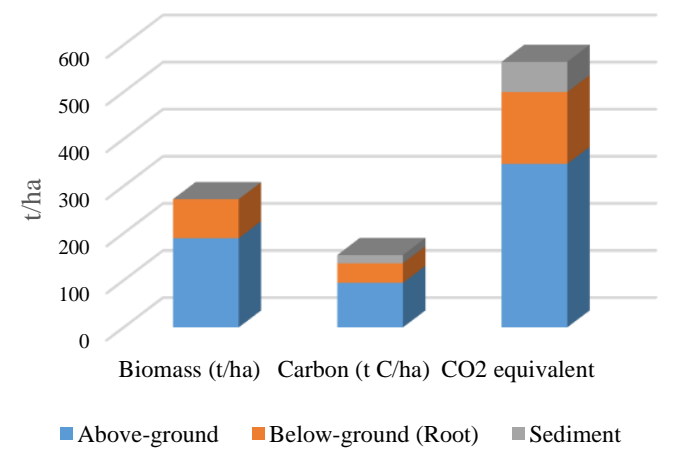

Figure 4. Mangrove biomass, $\mathrm{C}$-stocks and $\mathrm{CO}_{2}$ equivalent potential of Thalassery wetland.

The total carbon stock in different sectors of the study stations was $123.30 \pm 91.58 \mathrm{t} \mathrm{C} \mathrm{ha}^{-1}$ (sector I), $129.33 \pm 55.75 \mathrm{t} \mathrm{C}$ $\mathrm{ha}^{-1}$ (sector II) to $168.59 \pm 60.09 \mathrm{t} \mathrm{C} \mathrm{ha}^{-1}$ (sector III). The overall mean carbon stock value was $136.16 \pm 69.14 \mathrm{t} \mathrm{C} \mathrm{ha}^{-1}$ which was equivalent to $499.71 \mathrm{t} \mathrm{CO}_{2} \mathrm{ha}^{-1}$ sequestered and stored in the above ground and root biomass of Thalassery mangroves. The $\mathrm{T} / \mathrm{R}$ which is the ratio of the above-ground biomass and the root biomass ranged from 2.30 to 2.41 with an average value of 2.28 .

\section{C-stock in Mangrove Sediment}

The sediment bulk density varied from 0.47 (sector III) to $0.95 \mathrm{~g} \mathrm{~cm}^{-3}$ (sector II), with an overall mean bulk density value of $0.64 \mathrm{~g} \mathrm{~cm}^{-3}$. The mean sediment bulk density of sector I was $0.50 \mathrm{~g} \mathrm{~cm}^{-3}$. The mean percentage sediment organic carbon was $2.74,1.72$ and 5.24 in sectors I, II and III respectively, with an overall mean of $3.23 \%$. The mean total organic carbon stock in the sediment pool was $17.48 \pm 7.30 \mathrm{t} \mathrm{ha}^{-1}$ with $13.58 \pm 5.66$, $16.59 \pm 9.64$ and $24.87 \pm 6.61 \mathrm{t} \mathrm{ha}^{-1}$ in sectors I, II and III, respectively (Table 5).

\section{Total C-stock}

In the present study, the estimates of mean combined Cstocks in mangrove and sediment showed that this mangrove wetland stored $153.64 \mathrm{t} \mathrm{C}^{-1}$ (above-ground 94.63 $\pm 48.90 \mathrm{t} \mathrm{C}$ $\mathrm{ha}^{-1}$, root $41.53 \pm 20.24 \mathrm{t} \mathrm{C}^{-1}$ and sediment $17.48 \pm 7.30 \mathrm{t} \mathrm{C}^{-1}$ ) which was equivalent to $563.86 \mathrm{t} \mathrm{CO} 2 \mathrm{ha}^{-1}$ (above-ground $347.29 \mathrm{t} \mathrm{CO} 2 \mathrm{ha}^{-1}$, root $152.42 \mathrm{t} \mathrm{CO} 2 \mathrm{ha}^{-1}$ and sediment $64.15 \mathrm{t}$ $\mathrm{CO} 2 \mathrm{ha}^{-1}$ ) (Figure 4). The percentage share of carbon in the three carbon pools indicated that the above ground C-stock was the highest $(61.59 \%)$, followed by the below-ground (root) Cstock $(27.03 \%)$ and the C-stock of sediment (11.38\%).

\section{DISCUSSION}

Our studies in Thalassery estuarine wetland along the southwest coast of India has shown that the mangrove species $A$. officinalis was dominant among all the eight species recorded, with an average tree density of 729.37 individuals $\mathrm{ha}^{-1}$. However, $S$. alba had the highest DBH value when compared to A. officinalis. The DBH values obtained during the present study 
Table 5. Biomass, $C$-stock of mangroves and $C$-stock of sediment in different sectors of Thalassery wetland.

\begin{tabular}{|c|c|c|c|c|c|c|c|c|}
\hline \multirow[b]{2}{*}{ Sectors } & \multirow[b]{2}{*}{ Stations } & \multicolumn{2}{|c|}{ Above-ground } & \multicolumn{2}{|c|}{ Below-ground (root) } & \multicolumn{2}{|c|}{ Total } & \multirow{2}{*}{$\begin{array}{l}\text { Sediment Carbon } \\
\left(\mathrm{t} \mathrm{C} \mathrm{ha}^{-1}\right)\end{array}$} \\
\hline & & $\begin{array}{l}\text { Biomass } \\
\left(\mathrm{t} \mathrm{ha}^{-1}\right)\end{array}$ & $\begin{array}{l}\text { Carbon } \\
\left(\mathrm{t} \mathrm{ha}^{-1}\right)\end{array}$ & $\begin{array}{l}\text { Biomass } \\
\left(\mathrm{t} \mathrm{ha}^{-1}\right)\end{array}$ & $\begin{array}{l}\text { Carbon } \\
\left(\mathrm{t} \mathrm{ha}^{-1}\right)\end{array}$ & $\begin{array}{l}\text { Biomass } \\
\left(\mathrm{t} \mathrm{ha}^{-1}\right)\end{array}$ & $\begin{array}{l}\text { Carbon } \\
\left(\mathrm{t} C \mathrm{ha}^{-1}\right)\end{array}$ & \\
\hline \multirow[t]{6}{*}{ Sector I (Nettur) } & 1 & 6.41 & 3.21 & 4.61 & 2.31 & 11.02 & 5.51 & 2.48 \\
\hline & 2 & 35.77 & 17.89 & 19.76 & 9.88 & 55.53 & 27.77 & 15.00 \\
\hline & 3 & 160.04 & 80.02 & 68.05 & 34.03 & 228.09 & 114.05 & 13.90 \\
\hline & 4 & 262.92 & 131.46 & 112.04 & 56.02 & 374.96 & 187.48 & 14.75 \\
\hline & 5 & 331.74 & 165.87 & 139.18 & 69.59 & 470.92 & 235.46 & 17.97 \\
\hline & 6 & 234.80 & 117.40 & 104.20 & 52.10 & 339.00 & 169.50 & 17.37 \\
\hline Mean & & 171.95 & 85.98 & 74.64 & 37.32 & 246.59 & 123.30 & 13.58 \\
\hline SD & & 129.50 & 64.75 & 53.66 & 26.83 & 183.16 & 91.58 & 5.66 \\
\hline \multirow{7}{*}{$\begin{array}{l}\text { Sector II } \\
\text { (Koduvally) }\end{array}$} & 1 & 187.81 & 93.91 & 100.41 & 50.21 & 288.22 & 144.11 & 5.72 \\
\hline & 2 & 268.83 & 134.42 & 115.33 & 57.67 & 384.16 & 192.08 & 7.69 \\
\hline & 3 & 139.33 & 69.67 & 61.27 & 30.64 & 200.60 & 100.30 & 19.52 \\
\hline & 4 & 88.01 & 44.01 & 40.43 & 20.22 & 128.44 & 64.22 & 19.53 \\
\hline & 5 & 154.46 & 77.23 & 67.26 & 33.63 & 221.72 & 110.86 & 7.63 \\
\hline & 6 & 108.83 & 54.42 & 56.39 & 28.20 & 165.22 & 82.61 & 28.04 \\
\hline & 7 & 284.90 & 142.45 & 137.40 & 68.70 & 422.30 & 211.15 & 28.04 \\
\hline Mean & & 176.02 & 88.01 & 82.64 & 41.32 & 258.66 & 129.33 & 16.59 \\
\hline $\mathrm{SD}$ & & 76.02 & 38.01 & 35.47 & 17.73 & 111.49 & 55.75 & 9.64 \\
\hline \multirow{4}{*}{$\begin{array}{l}\text { Sector III } \\
\text { (Chonadam) }\end{array}$} & 1 & 180.02 & 90.01 & 72.15 & 36.08 & 252.17 & 126.09 & 24.47 \\
\hline & 2 & 220.94 & 110.47 & 92.57 & 46.29 & 313.51 & 156.76 & 34.34 \\
\hline & 3 & 185.48 & 92.74 & 84.58 & 42.29 & 270.06 & 135.03 & 20.34 \\
\hline & 4 & 367.44 & 183.72 & 145.48 & 72.74 & 512.92 & 256.46 & 20.33 \\
\hline Mean & & 238.47 & 119.24 & 98.70 & 49.35 & 337.17 & 168.59 & 24.87 \\
\hline SD & & 87.87 & 43.94 & 32.30 & 16.15 & 120.17 & 60.09 & 6.61 \\
\hline Overall Mean & & 189.26 & 94.63 & 83.06 & 41.53 & 272.32 & 136.16 & 17.48 \\
\hline SD & & 97.80 & 48.90 & 40.48 & 20.24 & 138.27 & 69.14 & 7.30 \\
\hline
\end{tabular}

for A. officinalis, E. agallocha and A. corniculatum were much lower when compared to the values obtained by Sahu, Manish Kumar, and Ravindranath (2016) for the same species in the Mahanadi mangrove wetland in the east coast of India.

The DBH values obtained for A. officinalis, S. alba, R. mucronata and E. agallocha in the present study are however comparable to the results obtained by Vinod et al. (2018) for the same species in Kadalundi estuarine wetland. Species-wise comparison of the total carbon stock revealed that A. officinalis had the highest value of $45.05 \pm 23.79 \mathrm{t} \mathrm{C} \mathrm{ha}^{-1}$, closely followed by the carbon values of $S$. alba $\left(44.48 \pm 30.71 \mathrm{t} \mathrm{C} \mathrm{ha}^{-1}\right)$. Highest carbon stock in $A$. officinalis was recorded even in the Kadalundi estuarine wetland (Vinod et al., 2018), as this species had the highest tree density as well as DBH. The overall mean above-ground biomass of mangroves of Thalassery estuarine wetland $\left(189.26 \pm 97.80 \mathrm{t} \mathrm{ha}^{-1}\right)$ recorded during the present study was much lower when compared to the above-ground biomass obtained by Kauffman et al. (2011) for the Micronesian mangroves (363 t ha-1 at Yap and $225 \mathrm{t} \mathrm{ha}^{-1}$ at Palau). The overall mean AGB of mangroves obtained during the present study was however much higher than the values obtained by Khan, Suwa, and Hagihara (2009) for the Manko Wetland, Okinawa, Japan (80.5 t ha $\left.{ }^{-1}\right)$; Chandra, Seca, and Abu Hena (2011) for the Sarawak Mangrove Forest, Malaysia (116.8 tha${ }^{1}$ ); Kathiresan et al. (2013) for the mangroves in the estuaries along the Bay of Bengal (60-117.7 $\left.\mathrm{t} \mathrm{ha}^{-1}\right)$; Golley, Odum, and Wilson (1962) for the mangroves of Puerto Rico (62.9 $\mathrm{t} \mathrm{ha}^{-1}$ ); Woodroffe (1985) for the mangroves in a flooded explosion crater in New Zealand $\left(6.8 \mathrm{t} \mathrm{ha}^{-1}\right.$ for short stunted mangroves to $104.1 \mathrm{t} \mathrm{ha}^{-1}$ for the taller mangroves of Avicennia marina var. resinifera); Murdiyarso et al. (2009) for the mangroves of North Sulawesi (61.4 t ha-1) and Sahu, Manish Kumar, and Ravindranath (2016) for the mangroves of Mahanadi mangrove wetland of India (124.91 $\mathrm{t} \mathrm{ha}^{-1}$ in natural mangroves and 125.55 $\mathrm{t} \mathrm{ha}^{-1}$ in planted mangrove stands). However, the present mean AGB values are almost comparable with the mean AGB value of $166.63 \mathrm{t} \mathrm{ha}^{-1}$ obtained for Kadalundi estuary, south-west coast of India (Vinod et al., 2018), $159 \mathrm{t} \mathrm{ha}^{-1}$ obtained for Rhizophora apiculata in Thailand (Christensen, 1978).

The biomass of mangroves is dependent on many factors such as the species, tree density, stem diameter, growth forms and age of the mangrove forest (Knox, 1986; Lugo and Snedaker, 1974; Woodroffe, 1985) and the review of the aboveground biomass values of mangroves also clearly indicated that the values vary from region to region depending on various factors mentioned above. The mangrove stands of the three sectors of Thalassery (Nettur, Koduvally and Chonadam) that were studied have a dominant standing stock of A. officinalis which has contributed significantly to the AGB, and our interaction with the local communities residing in the locality 
close to the wetland has given an indication that the stands of $A$. officinalis have been established over 4 decades.

The above-ground carbon pools obtained for the mangroves of Thalassery wetland during the present study $(94.63 \pm 48.90$ t C $\mathrm{ha}^{-1}$ ) were almost comparable with that of the studies of Vinod et al. (2018) for Kadalundi wetland, India (83.32 $\left.\mathrm{t} \mathrm{C} \mathrm{ha}^{-1}\right)$ and Kauffman et al. (2011) for Micronesian mangrove forests at Palau (104.4 t C ha-1). However, the present value was much lower when compared to the Micronesian mangrove forests at Yap (Kauffman et al. 2011; 169.2 t C ha $^{-1}$ ). The Thalassery wetland was found to have higher above-ground C-stock when compared to the natural mangrove stands of Mahanadi Mangrove Wetland (Sahu, Manish Kumar, and Ravindranath, 2016; $62.45 \mathrm{t} \mathrm{C} \mathrm{ha}^{-1}$ ), mangrove stocks of southern China (Chen et al., 2012; $\left.55 \mathrm{t} \mathrm{C} \mathrm{ha}^{-1}\right)$.

The overall mean carbon stock of root biomass $\left(41.53 \pm 20.24 \mathrm{t} \mathrm{C} \mathrm{ha}^{-1}\right)$ obtained during the present study is higher when compared to the values obtained for the mangrove stands of Kadalundi wetland, India $\left(34.96 \pm 4.30 \mathrm{t} \mathrm{C} \mathrm{ha}^{-1}\right.$; Vinod et al., 2018), southern China (21.4 t C ha-1, Chen et al., 2012), Mahanadi Mangrove Wetland, India $\left(27.86 \mathrm{t} \mathrm{C}^{-1}\right.$ for planted and $26.69 \mathrm{t} \mathrm{C} \mathrm{ha}^{-1}$ for natural mangrove stands, Sahu, Manish Kumar, and Ravindranath, 2016) and Tamil Nadu, India (12.9 to 18.1 t C ha ${ }^{-1}$, Kathiresan et al., 2013). However, the C-stock of root biomass obtained in Yap by Kauffman et al. (2011) was much higher than the present value obtained for the mangroves of Thalassery wetland.

The average ratio of the above-ground biomass and the root biomass $(T / R)$ in the present study was 2.28 . This value was comparable with that of the T/R values of Mahanadi Mangrove Wetland, India (T/R value of 2.3; Sahu, Manish Kumar, and Ravindranath, 2016), Kadalundi wetland, India (T/R value of 2.38, Vinod et al., 2018) and Micronesian mangrove forests (T/R value of 1.1 to 4.4; Kauffman et al. 2011). The T/R values of mangrove forests are generally lower when compared to the terrestrial trees since a substantial part of the biomass of mangroves get allocated in the root system so as to enable them to stand erect in muddy conditions of the coastal wetlands.

In the present study, the average organic carbon in the sediment carbon pool was $17.48 \mathrm{t} \mathrm{C} \mathrm{ha}^{-1}$ which was much lower than the values obtained for the Mahanadi Mangrove Wetland in the east coast of India (57.6 $\mathrm{t} \mathrm{C} \mathrm{ha}^{-1}$, Sahu, Manish Kumar, and Ravindranath, 2016), Micronesian mangroves (Palau 128.1 t C ha $^{-1}$, Yap 119.5 t C ha-1; Kauffman et al., 2011), Kadalundi, India (63.87 t C ha-1; Vinod et al., 2018), Okinawa, Japan (57.3 t $\mathrm{C} \mathrm{ha}^{-1}$; Khan, Suwa, and Hagihara, 2007). The sediment C-stock in Thalassery estuarine wetland constituted $11.37 \%$ of the total carbon stock (above ground carbon, root carbon and sediment carbon pools) and the mean sediment $\mathrm{C}$-stock obtained in the present study was equivalent to $64.15 \mathrm{t} \mathrm{CO}_{2} \mathrm{ha}^{-1}$ and the present study fully agrees with the fact that the sediments in a mangrove area serves as an important carbon pool (Donato et al., 2011; Kauffman and Donato, 2012; Kauffman et al., 2011). Although the sediment C-stock obtained for Thalassery wetland is less (based on carbon values of upper $30 \mathrm{~cm}$ depth), the values are indicative of the capacity of mangrove sediment to act as a carbon sink; however, Lawrence (2012) and Nellemann et al. (2009) have suggested that studies of carbon stock in different sediment depths would prove to be important.
The mangroves of Thalassery wetland (Nettur, Koduvally and Chonadam) cover an area of 5.8 ha. Considering the estimated total carbon stock of $153.64 \mathrm{t} \mathrm{C} \mathrm{ha}^{-1}$ in Thalassery wetland, it can be assumed that this wetland has the potential to sequester and store $891.11 \mathrm{t} \mathrm{C}$, equivalent to an estimated amount of $3270.37 \mathrm{t} \mathrm{CO}_{2}$. The present study thus signifies the potential of mangrove blue carbon ecosystem as an important carbon sink which is essential for climate change mitigation.

\section{CONCLUSIONS}

The mangrove wetlands are important habitats rendering many ecosystem services including fisheries, aquaculture, tourism, nursery and breeding grounds of fishes and invertebrates, feeding and nesting habitat of avian fauna, coastline protection, control of soil erosion, as a nutrient filter between land and sea and climate regulation. However, this critical habitat is vulnerable to anthropogenic pressures like dependency on mangroves for timber and firewood, conversion of mangrove areas for agriculture, clearing mangroves for aquaculture and coastal pollution. Worldwide there is an increasing awareness on the importance of mangroves as a source of carbon sink, in view of the climate change mitigation strategies. The increasing $\mathrm{CO}_{2}$ levels in the atmosphere warrants the need to identify efficient and acceptable approaches to reduce the same and reducing the atmospheric $\mathrm{CO}_{2}$ through carbon sequestration appears to be a more viable solution. The blue carbon ecosystems, particularly mangroves, are potential carbon sinks with the ability to store large quantities of carbon in their biomass and sediment. Considering an estimated total carbon stock of $153.64 \mathrm{t} \mathrm{C}^{-1}$ in Thalassery wetland, it can be assumed that the mangroves spread over $9 \mathrm{~km}^{2}$. in the state of Kerala, south India, will have the potential to sequester and store approximately $138,276 \mathrm{t} \mathrm{C}$. Therefore, it is imperative that the mangrove habitats need to be restored and protected as a climate change mitigating measure.

\section{ACKNOWLEDGMENTS}

The authors express their sincere gratitude to Dr. A. Gopalakrishnan, Director, ICAR-Central Marine Fisheries Research Institute, Kochi, India for providing facilities and support. The research work was carried out under the project 'National Innovations in Climate Resilient Agriculture' (NICRA), of the Indian Council of Agricultural Research (ICAR), Government of India.

\section{LITERATURE CITED}

Alongi, D.M.; Tirendi, F., and Clough, B.F., 2000. Belowground decomposition of organic matter in forests of the mangroves Rhizophora stylosa and Avicennia marina along the arid coast of Western Australia. Aquatic Botany, 68, 97-122.

Baran, E. and Hambrey, J., 1998. Mangrove conservation and coastal management in Southeast Asia; what impact on fishery resources? Marine Pollution Bulletin, 37, 431-440.

Barbier, E.B., 2000. Valuing the environment as input: Review of applications to mangrove-fishery linkages. Ecological Economics, 35, 47-61.

Chandra, I.A.; Seca, G., and Abu Hena, M.K., 2011. Aboveground biomass production of Rhizophora 
apiculata Blume in Sarawak mangrove forest. American Journal of Agricultural and Biological Sciences, 6, 469474.

Chen, L.; Zeng, X.; Tam, N.F.Y.; Lu, W.; Luo, Z.; Du, X., and Wang, J., 2012. Comparing carbon sequestration and stand structure of monoculture and mixed mangrove plantations of Sonneratia caseolaris and $S$. apetala in southern China. Forest Ecology and Management, 284, 222-229.

Christensen, B., 1978. Biomass and primary production of Rhizophora apiculata $\mathrm{Bl}$ in a mangrove in Southern Thailand. Aquatic Botany, 4, 43-52.

Danielsen, F.; Sorensen, M.K.; Olwig, M.F.; Selvam, V.; Parish, F.; Burgess, N.D.; Hiraishi, T.; Karunagaran, V.M.; Rasmussen, M.S.; Hansen, L.B.; Quarto, A., and Suryadiputra, N., 2005. The Asian tsunami; a protective role for coastal vegetation. Science, 310 (5748), 643.

Danielsen, F.; Sorensen, M.K.; Olwig, M.F.; Selvam, V.; Parish, F.; Burgess, N.D.; Topp-Jorgensen, E.; Hiraishi, T.; Karunagaran, V.M.; Rasmussen, M.S.; Hansen, L.B.; Quarto, A., and Suryadiputra, N., 2006. Coastal vegetation and the Asian tsunami - Response. Science, 311, 37-38.

Das, S. and Vincent, R., 2009. Mangroves protected villages and reduced death toll during Indian super cyclone. PNAS, $1-4$.

Dedysh, S.N.; Derakshani, M., and Liesack, W., 2001. Detection and enumeration of methanotrophs in acidic Sphagnum Peat by $16 \mathrm{~S}$ rRNA fluorescence in situ hybridization, including the use of newly developed oligonucleotide probes for Methylocella palustris. Applied and Environmental Microbiology, 67, 4850-4857.

Diele, K.; Koch, V., and Saint-Paul, U., 2005. Population structure and catch composition of the exploited mangrove crab Ucides cordatus in the Cacte estuary, north Brazil: indications of overfishing? Aquatic Living Resources, 18, 169-178.

Donato, D.C.; Boone Kauffman, J.; Murdiyarso, D.; Kurnianto, S.; Stidham, M., and Kanninen, M., 2011. Mangroves among the most carbon-rich forests in the tropics. Nature Geoscience, 4, 293-297.

Field, C.D., 1995. Impact of expected climate change on mangroves. Hydrobiologia, 295, 75-81.

Frontier Madagascar, 2005. A Field Manual for Survey Methods in Tropical Marine Ecosystems. In: Biddick, K.; Brown, L.F.; Markham, K.; Mayhew, E.M.; Robertson, A., and Smith, V. (eds.), Frontier Madagascar Environmental Research Report 17, Society for Environmental Exploration, UK, pp. 67.

Giri, C.; Ochieng, E.; Tieszen, L.L.; Zhu, Z.; Singh, A.; Loveland, T.; Masek, J., and Duke, N., 2011. Status and distribution of mangrove forests of the world using earth observation satellite data. Global Ecology and Biogeography, 20, 154-159.

Golley, F.B.; Odum, H.T., and Wilson, R.F., 1962. The structure and metabolism of a Puerto Rican red mangrove forest in May. Ecology, 43, 9-19.

India State of Forest Report, 2017. Forest Survey of India, Ministry of Environment, Forests \& Climate Change, Dehradun, India, 363 p.
Kathiresan, K.; Anburaj, R.; Gomathi V., and Saravanakumar, K., 2013. Carbon sequestration potential of Rhizophora mucronata and Avicennia marina as influenced by age, season, growth and sediment characteristics in south east coast of India. Journal of Coastal Conservation, 17, 397408.

Kathiresan, K. and Rajendran, N., 2005. Coastal mangrove forests mitigated tsunami. Estuarine, Coastal and Shelf Science, 65, 601-606.

Kauffman, J.B.; Heider, C.; Cole, T.G.; Dwire, K.A., and Donato, D.C., 2011. Ecosystem carbon stocks of Micronesian mangrove forests. Wetlands, 31, 343-352.

Kauffman, J.B. and Donato, D.C., 2012. Protocols for the Measurement, Monitoring and Reporting of Structure, Biomass and Carbon Stocks in Mangrove Forests. Working Paper 86, CIFOR, Bogor, Indonesia, 40 p.

Khan, M.N.I.; Suwa R., and Hagihara, A., 2007. Carbon and nitrogen pools in a mangrove stand of Kandelia obovata (S.L.) Yong: vertical distribution in the soil-vegetation system. Wetlands Ecology and Management, 15 (2), 141153.

Khan, M.N.I.; Suwa R., and Hagihara, A., 2009. Biomass and aboveground net primary production in a subtropical mangrove stand of Kandelia obovata (S.L.) Yong at Manko Wetland, Okinawa, Japan. Wetlands Ecology and Management, 17, 585-599.

Knox, G.A., 1986. Estuarine Ecosystems: A System Approach. Vol. I, CRC Press, Florida.289 p.

Komiyama, A.; Poungparn, S., and Kato, S., 2005. Common allometric equations for estimating the tree height of mangroves. Journal of Tropical Ecology, 21, 471-477.

Lawrence, A., 2012. Blue Carbon: A New Concept for Reducing the Impacts of Climate Change by Conserving Coastal Ecosystems in the Coral Triangle. WWFAustralia, Brisbane, Queensland, 21 p.

Le Quere, C.; Andres, R.J.; Boden, T.; Conway, T.; Houghton, R.A.; House, J.I.; Marland, G.; Peters, G.P.; van der Werf, G.; Ahlstrom, A.; Andrew, R.M.; Bopp, L.; Canadell, J.G.; Ciais, P.; Doney, S.C.; Enright, C.; Friedlingstein, P.; Huntingford, C.; Jain, A.K.; Jourdain, C.; Kato, E.; Keeling, R.F.; Klein Goldewijk, K.; Levis, S.; Levy, P.; Lomas, M.; Poulter, B.; Raupach, M.R.; Schwinger, J.; Sitch, S.; Stocker, B.D.; Viovy, N.; Zaehle, S., and Zeng, N., 2012. The global carbon budget 1959-2011. Earth System Science Data Discussions, 5, 1107-1157.

Lugo, A.E. and Snedaker, S.C., 1974. The ecology of mangroves. Annual Review of Ecology and Systematics, 5, 39-64.

Mumby, P.J.; Edwards, A.J.; Arias-Gonzalez, J.E.; Lindeman, K.C.; Blackwell, P.G.; Gall, A.; Gorczynska, M.I.; Harborne, A.R.; Pescod, C.L.; Renken, H.; Wabnitz, C.C.C., and Llewellyn, G., 2004. Mangroves enhance the biomass of coral reef fish communities in the Caribbean. Nature, 427, 533-536.

Murdiyarso, D.; Donato, D.; Kauffman, J.B.; Kurnianto, S.; Stidham M., and Kanninen, M., 2009. Carbon Storage in Mangrove and Peatland Ecosystems in Indonesia - A Preliminary Account from Plots in Indonesia. Working 
Paper 48, Centre for International Forestry Research, Bogor, Indonesia, $35 \mathrm{p}$.

Nellemann, C.; Corcoran, E.; Duarte, C.M.; Valdes, L.; De Young, C.; Fonseca, L., and Grimsditch, G., 2009. Blue Carbon: The Role of Healthy Oceans in Binding Carbon. A Rapid Response Assessment. United Nations Environment Programme, Birkelandn Trykkeri AS, Norway, $80 \mathrm{p}$.

Rivera-Monroy, V.H.; Torres, I.A.; Bahamon, N.; Newmark, F., and Twilley, R.R., 1999. The potential use of mangrove forests as nitrogen sinks of shrimp aquaculture pond effluents: The role of denitrification. Journal of World Aquaculture Society, 30 (1), 12-25.

Robertson, A.I. and Phillips, M.J., 1995. Mangroves as filters of shrimp pond effluent: Predictions and biogeochemical research needs. Hydrobiologia, 295, 311-321.

Ronnback, P., 1999. The ecological basis for economic value of seafood production supported by mangrove ecosystems. Ecological Economics, 29, 235-252.

Roy, S.D. and Krishnan, P., 2005. Mangrove stands of Andamans vis-à-vis tsunami. Current Science, 89, 18001804.

Sahu, S.C.; Manish Kumar, and Ravindranath, N.H., 2016. Carbon stocks in natural and planted mangrove forests of Mahanadi mangrove wetland, east coast of India. Current Science, 110 (12), 2253-2260.

Sahu, S.C.; Sahoo, K.; Jee, P.K., and Dhal, N.K., 2013. Floral and microbial dynamics in relation to the physicochemical constituents of the Devi estuary of Odisha coast of the Bay of Bengal, India. Indian Journal of Geomarine Sciences, 42 (1), 90-96.

Spalding M.; Kainuma M., and Collins, L., 2010. World Atlas of
Mangroves (version 3). A collaborative project of ITTO, ISME, FAO, UNEP-WCMC, UNESCO-MAB, UNUINWEH and TNC. London (UK): Earthscan, London, 319 p. URL: data.unep-wcmc.org/datasets/5.

Upadhyay, V.P.; Ranjan, R., and Singh, J.S., 2002. Humanmangrove conflicts; the way out. Current Science, 83 (11), 1328-1336.

Vermaat, J.E. and Thampanya, U., 2006. Mangroves mitigate tsunami damage, a further response. Estuarine, Coastal and Shelf Science, 69, 1-3.

Vinod, K.; Anasu Koya, A.; Kunhikoya, V.A.; Silpa, P.G.; Asokan, P.K.; Zacharia, P.U., and Joshi, K.K., 2018. Biomass and carbon stocks in mangrove stands of Kadalundi estuarine wetland, south-west coast of India. Indian Journal of Fisheries, 65 (2). 89-99.

Walkley, A. and Black, I.A., 1934. An examination of the Degtjareff method for determining soil organic matter and a proposed modification of the chromic acid titration method. Soil Science, 37, 29-37.

Woodroffe, C.D., 1985. Studies of a mangrove basin, Tuff Crater, New Zealand: I. Mangrove biomass and production of detritus. Estuarine Coastal and Shelf Science, 20, 265280.

World Agroforestry Centre, 2011. Databases. World Agroforestry Centre, Nairobi, Kenya. http://www.worldagroforestrycentre.org/our_products/data bases (May 11, 2011).

Yoshiro, M.; Michimasa, M.; Motohiko, K., and Phan, N.H., 1997. Mangroves as a coastal protection from waves in the Tong Kind delta, Vietnam. Mangroves Salt Marshes, 1, 127-135. 